Bangladesh J. Pl. Breed. Genet., 29(1): 21-30, 2016

\title{
GENETIC VARIABILITY, CHARACTER ASSOCIATION AND PATH ANALYSIS OF YIELD AND ITS COMPONENT TRAITS IN MAIZE (Zea mays L.)
}

\author{
M. N. Huda, M. S. Hossain and M. Sonom \\ Department of Genetics and Plant Breeding \\ Sher-e-Bangla Agricultural University \\ Dhaka 1207, Bangladesh
}

\begin{abstract}
The experiment was conducted in the experimental area of Sher-e-Bangla Agricultural University, Sher-e-Bangla Nagar, Dhaka during March to June, 2014 to study the genetic variability, correlation and path co-efficient analysis for yield and yield contributing characters of maize. In this experiment 25 maize genotypes were used as experimental materials. The experiment was laid out in Randomized Complete Block Design (RCBD) with three replications. Mean performance, variability, correlation matrix and path analysis on different yield contributing characters and yield of maize genotypes were estimated. The highest grain yield/plant (272.21 g) was recorded in the genotype of BARI Hybrid Maize-6, whereas the lowest grain yield/plant $(180.40 \mathrm{~g})$ from the genotype of NZ-003. Phenotypic coefficient of variation was higher than the genotypic coefficient of variation for all the yield contributing traits. In correlation study, significant positive association was recorded for grain yield/plant of maize genotypes with plant height (0.235), tassel height (0.359), number of grains/cob (0.854), cob length (0.390), cob diameter (0.313) and weight of 1000-grains (0.689). Path analysis revealed that days to initiation of male flower had positive direct effect $(0.132)$, days to initiation of female flower had negative direct effect (-0.254), days to maturity had positive direct effect (0.178), plant height had positive direct effect (0.314), tassel height had positive direct effect $(0.234)$, ear length had positive direct effect $(0.197)$, number of grains/cob had negative direct effect $(-0.095)$, cob length had positive direct effect (0.167), cob diameter had positive direct effect (0.168) and that weight of 1000grains had positive direct effect $(0.217)$ on yield / plant.
\end{abstract}

Keywords: Maize; variability; correlation; path analysis.

\section{INTRODUCTION}

Maize (Zea mays L.) belongs to the family Poaceae is one of the most important photo-insensitive, cross pollinated cereal crops and ranks $3^{\text {rd }}$ in acreage and production in Bangladesh. It is the third most important grain crop after wheat and rice and it accounts for $4.8 \%$ of the total cropped land area and $3.5 \%$ of the value of agricultural output (Ahmad et al., 2011). It was originated from subtropical regions, probably from the highlands of Mexico and today it is a leading crop in many temperate regions. In Bangladesh, maize cultivated in about 152 thousand hectares of land and total annual production is 887 thousand Metric tons with an average yield of $5.83 \mathrm{t} \mathrm{ha}^{-1}$ (BBS, 2014). Introduction of quality protein maize (QPM) in Bangladesh is a long aspiration to feed the million malnourished populations. Thus, maize should get priority considering the protein malnutrition of the people, because it contains more digestible protein than the other cereals (Ahamed, 2010). Maize is grown as grains as well as fodder crop, although 
it has been cultivated in limited area ranking $3^{\text {rd }}$ most important cereal crops in Bangladesh, recently its cultivation gaining popularity and it occupied $2^{\text {nd }}$ position next to rice in the preceding year (DAE, 2012). As food, it can be consumed directly as green cob, roasted cob or popped grain. Maize grain can be used for human consumption in various ways such as corn meal, fried grain and flour. Moreover, $100 \mathrm{~g}$ maize grains contain $90 \mathrm{mg}$ carotene, $1.8 \mathrm{mg}$ niacin $0.8 \mathrm{mg}$ thiamin and $0.1 \mathrm{mg}$ riboflavin (Chowdhury and Islam, 1993). Maize oil is used as the best quality edible oil. Green parts of the plant and grain are used as the feed of livestock and poultry. Stover and dry leaves are used as good fuel (Ahmed, 1994). The important industrial use of maize includes in the manufacture of starch and other products such as glucose, high fructose sugar, maize oil, alcohols, baby foods and breakfast cereals (Kaul, 1985).. Maize is one of the most productive $\mathrm{C} 4$ plant with a high rate of photosynthetic activity. Maize has the highest potential for carbohydrate production per unit area per day. Stem and foliage of maize plant can be used as livestock feed. Stalk, dry leave covering of cobs (husks) and shelled cobs can be used as fuel (Ahmed et al., 2011). It can be grown all the year round in Bangladesh, and fitted in the gap between the main cropping seasons without affecting the major crops. It can also be grown in flood prone areas under no tillage, and with no inputs (Efferson, 1982). With its multipurpose properties, it will undoubtedly play a vital role in reducing the food shortage around the world, especially in Bangladesh. Maize is being cultivated all over the world but the yield of maize is low in Bangladesh as compared to the other maize growing countries. To guarantee high yield of maize crop, farmers often grow improved varieties usually from different sources either alone or with other local varieties, resulting in diversity among cultivars grown within and among farmers. Genetic variability, which is a heritable difference among cultivars, is required in an appreciable level within a population to facilitate and sustain an effective long-term plant breeding program. Progress from selection has been reported to be directly related to the magnitude of genetic variance in the population (Helm et al., 1989; Hallauer and Miranda, 1995; Tabanao and Bernardo, 2005). Large amount of genetic variability has been observed to occur in the original accessions and races among sampled population representing different climatic, geographical regions (Ilarslan et al., 2002). Abayi et al. (2004) observed significant genetic variation in important agronomic traits, especially earliness to sufficiently justify the initiation of selection program. The results of Jotshi et al. (1988), Alvarez and Lasa (1994), Lu et al. (1994) and Zhang et al. (1995) demonstrated the importance of quantifying genetic variability among maize cultivars grown in an area before initiation of breeding program. Information of genetics on yield and other associated characters those are influenced by the local environment is limited but such information is prerequisite to plan any breeding program for development of high yielding maize (Agrawal, 2002). Among the various traits, grain yield in maize is the most important and complex quantitative traits controlled by numerous genes (Zdunic et al., 2008). Yield being a complex trait, is considerably influenced by different contributing yield components like ear height, plant height and 1000-grain weight (Rahman et al., 1995). The yield of hybrids obtained from inbred lines that have high grain yield. Likewise, the yield of hybrids obtained from inbred lines that have low grain yield. It was attempted to select hybrid maize parent lines that give the highest yield using discriminate analysis techniques $(\mathrm{Oz}, 2012)$. Grain yield is directly and positively associated with ear weight. Improvements in yield can be achieved by selection for grain yield, plant height and ear height (Prodhan, 1997). The additive genetic variance component is the most important component of genetic variability for all the traits $(\mathrm{Oz}$, 2012; Betran and Hallauer, 1996). With conceiving the above scheme and discussion in mind, the study was conducted to know the yield potentiality of different maize 
genotypes, to know the nature of association of traits, direct and indirect relation between yield contributing characters of maize genotypes and to screen out the suitable maize genotypes for future breeding program.

\section{MATERIALS AND METHODS}

The field experiment was conducted during the period of March to June, 2014.The present research work was conducted in the experimental area of Sher-eBangla Agricultural University, Sher-e-Bangla Nagar, Dhaka.The experiment was laid out in Randomized Complete Block Design (RCBD) with three replications. The total area of the experimental plot was $1557.5 \mathrm{~m}^{2}$ with length $89.0 \mathrm{~m}$ and width $17.5 \mathrm{~m}$. The total area was divided into three equal blocks. Each block was divided into 25 plots where 25 maize genotypes were allotted at random. There were 75 unit plots altogether in the experiment. The size of the each plot was $4.5 \mathrm{~m} \times 3.0 \mathrm{~m}$. The distance maintained between two blocks and two plots were $1.0 \mathrm{~m}$ and $0.5 \mathrm{~m}$, respectively.Green manure and decomposed organic matter are used @ of 6.0 ton /hectare before final land preparation. The chemical fertilizers such as Urea, TSP, MOP, Gypsum, Boric acid and Zinc sulphate were applied in the rows at the rate of 50-195-35-100-10-10 and $10 \mathrm{~kg} / \mathrm{ha}$ respectively as basal doze. The rest $120 \mathrm{~kg}$ Urea was applied in three equal splits (i.e. $40 \mathrm{~kg} / \mathrm{splits}$ ) at 25 , 45 and 65 days after planting as side dressing, 3-5 cm away from the plant and the furrows of the fertilizer are hilled up immediately. At the time of third dressing of Urea $35 \mathrm{~kg}$ of MOP (rest) was also used.In this experiment 25 maize genotypes (Table 1) were used as experimental materials which were produced in the 2012-2013 cropping season, and the purity and germination percentage were leveled as $94 \%$ and $91 \%$, respectively.

Table 1. Name and origin of the maize genotypes used in the present study

\begin{tabular}{c|l|c|c|l|c}
\hline SL.\# & Genotypes & $\begin{array}{c}\text { Source } \\
\text { of origin }\end{array}$ & SL.\# & Genotypes & Source of origin \\
\hline 01. & BARI Hybrid Maize-6 & BARI & 14. & Pioneer-3785 & Petrocem Co. \\
02. & BARI Hybrid Maize-7 & BARI & 15. & Pioneer-07 & Petrocem Co. \\
03. & BARI Hybrid Maize-9 & BARI & 16. & GP-50 & Getco \\
04. & Shuvra & BARI & 17. & 987 Aotu & Getco \\
05. & Barnali & BARI & 18. & GP-901 & Getco \\
06. & AS-999 & ACI & 19. & GP-838 & Getco \\
07. & Kaberi-369 & ACI & 20. & PAC-555 & Lal Teer \\
08. & NZ-001 & ACI & 21. & Elite & Lal Teer \\
09. & NZ-003 & ACI & 22. & Krishibid PS-102 & Krishibid group \\
10. & NZ-510 & ACI & 23. & Krishibid Bhutta-550 & Krishibid group \\
11. & $25 K S S$ & ACI & 24. & Krishibid-222 & Krishibid group \\
12. & ACI-3110 & ACI & 25. & AGRO G8255 & Agoa \\
13. & BRAC-984 & BRAC & & & \\
\hline
\end{tabular}

Data was recorded on days to initiation of male flower, days to initiation of female flower, days to maturity, plant height $(\mathrm{cm})$, tassel height $(\mathrm{cm})$, ear length $(\mathrm{cm})$, number of grains/cob, cob length $(\mathrm{cm})$, cob diameter $(\mathrm{mm})$, weight of 1000-grains and grain yield/ plant. Genotypic and phenotypic variances were estimated according to the formula given by Johnson et al. (1955). Genotypic and phenotypic correlation coefficients were calculated as according to Miller et al. (1958). Path coefficient analysis was estimated according to method suggested by Dewey and Lu (1959). 


\section{RESULTS AND DISCUSSION}

Mean sum of square due to genotypes were significant for all the characters suggesting presence of considerable genetic variation in respect of various characters. The analysis of variance indicated the existence of sufficient amount of variability among genotypes for all the characters studied so the genotypes were widely variable. In the present study, the phenotypic variance was in general higher than the genotypic variance for all the characters. Thus it suggests the substantial influence of environment besides the genetic variation for expression of these traits.

Table 2. Analysis of variance (ANOVA) of the data on yield attributes and yield of different maize genotypes

\begin{tabular}{l|c|c|c|c|c|c}
\hline \multirow{2}{*}{ Characters } & \multicolumn{3}{c|}{ Degrees of freedom (df) } & \multicolumn{3}{c}{ Mean Sum of Square (MSS) } \\
\cline { 2 - 7 } & Replication & Genotypes & Error & Replication & Genotypes & Error \\
\hline $\begin{array}{l}\text { Days to initiation of male } \\
\text { flower }\end{array}$ & 2 & 24 & 48 & 1.213 & $33.486^{*}$ & 8.686 \\
$\begin{array}{l}\text { Days to initiation } \\
\text { female flower }\end{array}$ & 2 & & & & & \\
Days to maturity & 24 & 48 & 5.880 & $37.013 * *$ & 6.838 \\
Plant height (cm) & 2 & 24 & 48 & 5.813 & $53.598^{*}$ & 20.216 \\
Tassel height (cm) & 2 & 24 & 48 & 64.819 & $190.585 * *$ & 24.644 \\
Ear length (cm) & 2 & 24 & 48 & 6.559 & $20.065^{* *}$ & 4.524 \\
Number of grains/cob & 2 & 24 & 48 & 0.120 & $29.341 *$ & 5.780 \\
Cob length (cm) & 2 & 24 & 48 & 1187.487 & $4187.134 *$ & 161.643 \\
Cob diameter (mm) & 2 & 24 & 48 & 0.238 & $3.142 * *$ & 0.349 \\
Weight of 1000-grains (g) & 2 & 24 & 48 & 2.920 & $9.620^{* *}$ & 2.248 \\
Grain yield/plant (g) & 2 & 24 & 48 & 241.773 & $1186.639 * *$ & 294.204 \\
& 2 & 24 & 48 & 168.070 & $1421.238^{* *}$ & 158.309 \\
\hline
\end{tabular}

**: Significant at 0.01 level of probability;

*: Significant at 0.05 level of probability

Highly significant positive association was recorded for days to initiation of male flower with days to initiation of female flower (0.892), days to maturity (0.475) and ear length (0.940) (Table 4). Highly significant positive association was recorded for days to initiation of female flower with days to initiation of male flower (0.892), days to maturity $(0.516)$ and ear length $(0.832)$ (Table 4$)$. Highly significant positive association was recorded for days to maturity of maize genotypes with days to initiation of male flower (0.475), days to initiation of female flower (0.516) tassel height $(0.320)$ and ear length (0.475) (Table 4). Highly significant positive association was recorded for plant height of maize genotypes with tassel height (0.271), cob diameter (0.817) and yield/plant (0.235) (Table 4). Highly significant positive association was recorded for tassel height of maize genotypes with days to maturity (0.320), plant height $(0.271)$, cob length (0.312), cob diameter (0.308), weight of 1000-grains (0.320) and grain yield/plant $(0.359)$ and significant positive association was recorded in number of grains/cob $(0.243)$ (Table 4). Highly significant positive association was recorded for ear length of maize genotypes with days to initiation of male flower (0.940), days to initiation of female flower (0.832) and days to maturity (0.475) (Table 4). Shahrokhi and Khorasani (2013) reported that total yields showed significant association with ear height of maize. Highly significant positive association was recorded for number of grains/cob of maize genotypes with tassel height (0.243), cob length (0.373), cob diameter (0.249) and grain yield/plant (0.854) (Table 4). 
Table 3. Mean performance of yield attributes and yield of different maize genotypes

\begin{tabular}{|c|c|c|c|c|c|c|c|c|}
\hline Genotypes & $\begin{array}{l}\text { Days to } \\
\text { initiation of } \\
\text { male flower }\end{array}$ & $\begin{array}{c}\text { Days to } \\
\text { initiation of } \\
\text { female flower }\end{array}$ & $\begin{array}{l}\text { Days to } \\
\text { maturity }\end{array}$ & $\begin{array}{c}\text { Tassel } \\
\text { height }(\mathrm{cm})\end{array}$ & $\begin{array}{l}\text { Number of } \\
\text { grains/cob }\end{array}$ & $\begin{array}{l}\text { Cob diameter } \\
(\mathrm{mm})\end{array}$ & $\begin{array}{c}\text { Weight of } \\
\text { 1000-grains } \\
\text { (g) }\end{array}$ & $\begin{array}{c}\text { Grain } \\
\text { yield/plant } \\
\text { (g) }\end{array}$ \\
\hline BARI Hybrid Maize-6 & $65.00 \mathrm{~d}$ & $68.33 \mathrm{c}$ & $101.67 \mathrm{e}$ & $47.81 \mathrm{a}$ & $629.12 \mathrm{a}$ & $35.84 \mathrm{a}$ & $432.67 \mathrm{a}$ & $272.21 \mathrm{a}$ \\
\hline BARI Hybrid Maize-7 & $70.33 \mathrm{~b}-\mathrm{d}$ & $71.00 \mathrm{bc}$ & $113.00 \mathrm{a}-\mathrm{d}$ & $44.45 \mathrm{a}-\mathrm{e}$ & $592.05 \mathrm{a}-\mathrm{c}$ & $34.08 \mathrm{a}-\mathrm{d}$ & $376.00 \mathrm{~b}-\mathrm{f}$ & $222.33 \mathrm{~b}-\mathrm{d}$ \\
\hline BARI Hybrid Maize-9 & $68.33 \mathrm{~b}-\mathrm{d}$ & $69.33 \mathrm{c}$ & 109.67 a-e & $43.67 \mathrm{a}-\mathrm{e}$ & $496.36 \mathrm{de}$ & $34.06 \mathrm{a}-\mathrm{d}$ & $370.67 \mathrm{~b}-\mathrm{f}$ & $184.11 \mathrm{~d}$ \\
\hline Shuvra & $67.00 \mathrm{~cd}$ & $68.67 \mathrm{c}$ & $105.67 \mathrm{de}$ & $46.40 \mathrm{a}-\mathrm{c}$ & $589.40 \mathrm{a}-\mathrm{d}$ & $31.42 \mathrm{~b}-\mathrm{e}$ & $363.67 \mathrm{~d}-\mathrm{f}$ & $214.22 \mathrm{~b}-\mathrm{d}$ \\
\hline Barnali & $69.00 \mathrm{~b}-\mathrm{d}$ & $69.67 \mathrm{c}$ & 110.00 a-e & 44.59 a-e & $525.16 \mathrm{c}-\mathrm{e}$ & $31.60 \mathrm{~b}-\mathrm{e}$ & $381.33 \mathrm{~b}-\mathrm{f}$ & $200.43 \mathrm{~cd}$ \\
\hline AS-999 & $68.33 \mathrm{~b}-\mathrm{d}$ & $70.00 \mathrm{c}$ & $113.67 \mathrm{a}-\mathrm{d}$ & $46.47 \mathrm{a}-\mathrm{c}$ & $556.66 \mathrm{a}-\mathrm{e}$ & $34.85 \mathrm{ab}$ & $373.00 \mathrm{~b}-\mathrm{f}$ & $207.73 \mathrm{~cd}$ \\
\hline Kaberi-369 & $69.67 \mathrm{~b}-\mathrm{d}$ & $71.67 \mathrm{bc}$ & $115.33 \mathrm{a}-\mathrm{d}$ & $45.73 \mathrm{a}-\mathrm{c}$ & $616.49 \mathrm{ab}$ & $33.99 \mathrm{a}-\mathrm{d}$ & $410.67 \mathrm{a}-\mathrm{c}$ & $253.15 \mathrm{ab}$ \\
\hline NZ-001 & $69.67 \mathrm{~b}-\mathrm{d}$ & $71.67 \mathrm{bc}$ & $107.00 \mathrm{~b}-\mathrm{e}$ & 43.97 a-e & 542.17 a-e & $33.07 \mathrm{a}-\mathrm{d}$ & $392.00 \mathrm{a}-\mathrm{f}$ & $212.50 \mathrm{~cd}$ \\
\hline NZ-003 & $69.00 \mathrm{~b}-\mathrm{d}$ & $70.33 \mathrm{bc}$ & 110.67 a-e & $41.95 \mathrm{a}-\mathrm{e}$ & $512.35 \mathrm{c}-\mathrm{e}$ & $34.66 \mathrm{a}-\mathrm{c}$ & $354.00 \mathrm{f}$ & $180.40 \mathrm{~d}$ \\
\hline NZ-510 & $71.67 \mathrm{a}-\mathrm{d}$ & $72.67 \mathrm{bc}$ & $114.67 \mathrm{a}-\mathrm{d}$ & $46.44 \mathrm{a}-\mathrm{c}$ & 539.20 a-e & $34.77 \mathrm{a}-\mathrm{c}$ & $378.33 \mathrm{~b}-\mathrm{f}$ & $204.94 \mathrm{~cd}$ \\
\hline $25 \mathrm{KSS}$ & $73.67 \mathrm{a}-\mathrm{d}$ & $75.67 \mathrm{a}-\mathrm{c}$ & $117.67 \mathrm{ab}$ & $45.96 \mathrm{a}-\mathrm{c}$ & 520.89 c-e & $34.33 \mathrm{a}-\mathrm{d}$ & $374.67 \mathrm{~b}-\mathrm{f}$ & $195.33 \mathrm{~cd}$ \\
\hline ACI-3110 & $69.67 \mathrm{~b}-\mathrm{d}$ & $70.67 \mathrm{bc}$ & $114.33 \mathrm{a}-\mathrm{d}$ & $46.90 \mathrm{ab}$ & 552.01 a-e & $33.59 \mathrm{a}-\mathrm{d}$ & $367.33 \mathrm{c}-\mathrm{f}$ & $202.88 \mathrm{~cd}$ \\
\hline BRAC-984 & $70.33 \mathrm{~b}-\mathrm{d}$ & $71.67 \mathrm{bc}$ & $110.33 \mathrm{a}-\mathrm{e}$ & $42.00 \mathrm{a}-\mathrm{e}$ & $500.68 \mathrm{c}-\mathrm{e}$ & $32.13 \mathrm{a}-\mathrm{d}$ & $385.00 \mathrm{~b}-\mathrm{f}$ & $193.22 \mathrm{~cd}$ \\
\hline Pioneer-3785 & $72.33 \mathrm{a}-\mathrm{d}$ & $74.00 \mathrm{a}-\mathrm{c}$ & $112.67 \mathrm{a}-\mathrm{d}$ & $41.49 \mathrm{~b}-\mathrm{e}$ & 499.00 c-e & $32.54 \mathrm{a}-\mathrm{d}$ & $368.67 \mathrm{~b}-\mathrm{f}$ & $183.50 \mathrm{~d}$ \\
\hline Pioneer-07 & $72.33 \mathrm{a}-\mathrm{d}$ & $74.67 \mathrm{a}-\mathrm{c}$ & $111.67 \mathrm{a}-\mathrm{e}$ & 42.89 a-e & 529.74 b-e & $30.65 \mathrm{c}-\mathrm{e}$ & $407.00 \mathrm{a}-\mathrm{d}$ & $215.58 \mathrm{~b}-\mathrm{d}$ \\
\hline GP-50 & $71.67 \mathrm{a}-\mathrm{d}$ & $74.00 \mathrm{a}-\mathrm{c}$ & $106.00 \mathrm{c}-\mathrm{e}$ & $40.35 \mathrm{c}-\mathrm{e}$ & 539.35 a-e & $35.79 \mathrm{a}$ & $387.67 \mathrm{~b}-\mathrm{f}$ & $209.28 \mathrm{~cd}$ \\
\hline 987 Aotu & $73.00 \mathrm{a}-\mathrm{d}$ & $74.33 \mathrm{a}-\mathrm{c}$ & 109.67 a-e & $41.63 \mathrm{~b}-\mathrm{e}$ & $511.59 \mathrm{c}-\mathrm{e}$ & $32.51 \mathrm{a}-\mathrm{d}$ & $365.67 \mathrm{~d}-\mathrm{f}$ & $186.72 \mathrm{~cd}$ \\
\hline GP-901 & $73.00 \mathrm{a}-\mathrm{d}$ & $74.67 \mathrm{a}-\mathrm{c}$ & $111.67 \mathrm{a}-\mathrm{e}$ & $40.70 \mathrm{c}-\mathrm{e}$ & 547.51 a-e & $35.47 \mathrm{ab}$ & $382.00 \mathrm{~b}-\mathrm{f}$ & $209.45 \mathrm{~cd}$ \\
\hline GP-838 & $72.33 \mathrm{a}-\mathrm{d}$ & $74.67 \mathrm{a}-\mathrm{c}$ & 110.00 a-e & $40.95 \mathrm{~b}-\mathrm{e}$ & 546.22 a-e & $33.27 \mathrm{a}-\mathrm{d}$ & $375.67 \mathrm{~b}-\mathrm{f}$ & $204.57 \mathrm{~cd}$ \\
\hline PAC-555 & $72.33 \mathrm{a}-\mathrm{d}$ & $73.67 \mathrm{a}-\mathrm{c}$ & 109.00 a-e & 43.31 a-e & 499.38 c-e & $33.70 \mathrm{a}-\mathrm{d}$ & $365.33 \mathrm{~d}-\mathrm{f}$ & $183.49 \mathrm{~d}$ \\
\hline Elite & $73.67 \mathrm{a}-\mathrm{d}$ & $74.67 \mathrm{a}-\mathrm{c}$ & $115.00 \mathrm{a}-\mathrm{d}$ & $38.87 \mathrm{e}$ & 568.29 a-e & $33.13 \mathrm{a}-\mathrm{d}$ & 401.67 a-e & $228.20 \mathrm{bc}$ \\
\hline Krishibid PS-102 & $77.00 \mathrm{ab}$ & $78.33 \mathrm{ab}$ & $117.00 \mathrm{a}-\mathrm{c}$ & $45.91 \mathrm{a}-\mathrm{c}$ & $494.42 \mathrm{e}$ & $33.09 \mathrm{a}-\mathrm{d}$ & $410.33 \mathrm{a}-\mathrm{c}$ & $202.74 \mathrm{~cd}$ \\
\hline Krishibid Bhutta-550 & $80.00 \mathrm{a}$ & $81.67 \mathrm{a}$ & $117.00 \mathrm{a}-\mathrm{c}$ & $41.29 \mathrm{~b}-\mathrm{e}$ & $513.26 \mathrm{c}-\mathrm{e}$ & 30.44 de & $412.00 \mathrm{ab}$ & $211.70 \mathrm{~cd}$ \\
\hline Krishibid-222 & $75.33 \mathrm{a}-\mathrm{c}$ & $75.67 \mathrm{a}-\mathrm{c}$ & $114.33 \mathrm{a}-\mathrm{d}$ & $39.09 \mathrm{de}$ & $510.13 \mathrm{c}-\mathrm{e}$ & $28.20 \mathrm{e}$ & $361.67 \mathrm{ef}$ & $183.58 \mathrm{~d}$ \\
\hline AGRO G8255 & $76.67 \mathrm{ab}$ & $81.33 \mathrm{a}$ & $120.00 \mathrm{a}$ & $45.14 \mathrm{a}-\mathrm{d}$ & $515.16 \mathrm{c}-\mathrm{e}$ & $33.00 \mathrm{a}-\mathrm{d}$ & 361.33 ef & $186.24 \mathrm{~cd}$ \\
\hline Mean & 71.67 & 73.33 & 112.00 & 43.52 & 537.86 & 33.21 & 382.33 & 205.94 \\
\hline $\mathrm{CV}(\%)$ & 6.03 & 5.60 & 4.91 & 7.09 & 8.64 & 6.21 & 5.81 & 10.40 \\
\hline
\end{tabular}


Table 4. Correlation coefficients of yield attributes and yield of different maize genotypes

\begin{tabular}{|c|c|c|c|c|c|c|c|c|c|c|c|}
\hline Characters & 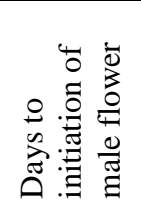 & 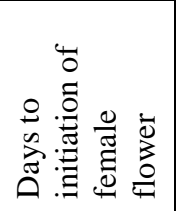 & 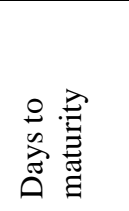 & 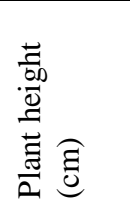 & 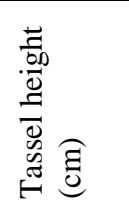 & 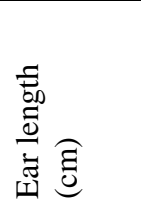 & 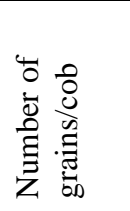 & 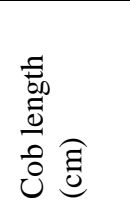 & 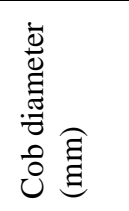 & 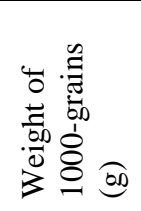 & 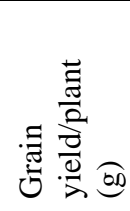 \\
\hline $\begin{array}{l}\text { Days to initiation of } \\
\text { male flower }\end{array}$ & 1.00 & & & & & & & & & & \\
\hline $\begin{array}{l}\text { Days to initiation of } \\
\text { female flower }\end{array}$ & $0.892 * *$ & 1.00 & & & & & & & & & \\
\hline Days to maturity & $0.475^{* *}$ & $0.516^{* *}$ & 1.00 & & & & & & & & \\
\hline Plant height $(\mathrm{cm})$ & -0.055 & -0.122 & 0.054 & 1.00 & & & & & & & \\
\hline Tassel height (cm) & -0.071 & -0.073 & $0.320 * *$ & $0.271 *$ & 1.00 & & & & & & \\
\hline Ear length $(\mathrm{cm})$ & $0.940 * *$ & $0.832 * *$ & $0.475 * *$ & -0.058 & 0.017 & 1.00 & & & & & \\
\hline Number of grains/cob & -0.214 & -0.208 & -0.172 & 0.164 & $0.243 *$ & $-0.226^{*}$ & 1.00 & & & & \\
\hline Cob length $(\mathrm{cm})$ & $-0.380 * *$ & $-0.344 * *$ & 0.001 & 0.171 & $0.312 * *$ & $-0.299 * *$ & $0.373 * *$ & 1.00 & & & \\
\hline Cob diameter $(\mathrm{mm})$ & -0.201 & $-0.240 *$ & -0.038 & $0.817 * *$ & $0.308 * *$ & -0.187 & $0.249 *$ & 0.181 & 1.00 & & \\
\hline Weight of 1000 -grains (g) & 0.016 & 0.013 & 0.065 & 0.187 & $0.320 * *$ & 0.048 & 0.213 & 0.208 & $0.222 *$ & 1.00 & \\
\hline Grain yield/plant $(\mathrm{g})$ & -0.155 & -0.149 & -0.099 & $0.235^{*}$ & $0.359 * *$ & -0.147 & $0.854 * *$ & $0.390 * *$ & $0.313 * *$ & $0.689 * *$ & 1.00 \\
\hline
\end{tabular}


Highly significant positive association was recorded for cob length of maize genotypes with days to tassel height (0.312), number of grains/cob (0.373) and grain yield/plant (0.390) (Table 4). Significant positive association was recorded for cob diameter of maize genotypes with plant height (0.817), tassel height (0.308), number of grains/cob (0.249), weight of 1000-grains (0.222) and grain yield/plant (0.313) (Table 6).Highly significant positive association was recorded for weight of 1000-grains of maize genotypes with tassel height $(0.320)$, cob diameter (0.222) and grain yield/plant $(0.689)$ (Table 4).Highly significant positive association was recorded for grain yield/plant of maize genotypes with plant height $(0.235)$, tassel height $(0.359)$, number of grains/cob (0.854), cob length (0.390), cob diameter (0.313) and weight of 1000-grains $(0.689$. Tusuz and Balabanl (1997) reported that yield was significantly correlated with $50 \%$ silking date $(r=0.67)$, plant height $(r=0.50)$, ear height $(r=0.42)$ and harvest moisture percentage $(r=0.43)$.Path co-efficient analysis denotes the components of correlation coefficient within different traits into the direct and indirect effects and indicates the relationship in more meaningful way. The results of the path co-efficient analysis are presented in Table 3.Path analysis revealed that days to initiation of male flower had positive direct effect (0.132) on yield/plant (Table 4).Path analysis revealed that days to initiation of female flower had negligible positive indirect effect through plant height, number of grains/cob and weight of 1000-grains.Path analysis revealed that days to maturity had positive direct effect (0.178) on yield/plant (Table 4). It showed negligible positive indirect effect through days to initiation of male flower, days to initiation of female flower, days to maturity, plant height, ear length and number of grains/cob.

Path analysis revealed that plant height had positive direct effect (0.314) on yield/plant (Table 5). It showed negligible positive indirect effect through days to initiation of male flower, days to initiation of female flower, number of grains/cob and cob diameter. Path analysis revealed that tassel height had positive direct effect $(0.234)$ on yield/plant (Table 5). It showed negligible positive indirect effect through days to maturity, ear length, cob length and weight of 1000-grains, while tassel height showed negative indirect effect through days to initiation of male flower, days to initiation of female flower, plant height, number of grains/cob and cob diameter. Path analysis revealed that ear length had positive direct effect $(0.197)$ on yield/plant (Table 5). It showed negligible positive indirect effect through days to initiation of female flower, plant height, number of grains/cob, cob length and cob diameter. Path analysis revealed that number of grains/cob had negative direct effect $(-0.095)$ on yield/plant (Table 5). It showed negligible positive indirect effect through days to initiation of male flower, days to maturity, tassel height, ear length and weight of 1000-grains. Path analysis revealed that cob length had positive direct effect (0.167) on yield/plant (Table 5). It showed negligible positive indirect effect through days to initiation of male flower, days to initiation of female flower, plant height and ear length, while cob length showed negative indirect effect through days to maturity, tassel height, number of grains/cob, cob diameter and weight of 1000-grains.Path analysis revealed that cob diameter had positive direct effect (0.168) on yield/plant (Table 5). It showed negligible positive indirect effect through days to maturity, tassel height, ear length, number of grains/cob and weight of 1000 -grains. Path analysis revealed that weight of 1000-grains had positive direct effect $(0.217)$ on yield/plant (Table 5). It showed negligible positive indirect effect through days to initiation of male flower, days to initiation of female flower, days to maturity, tassel height and number of grains/cob. 
Table 5. Path coefficients for yield attributes and yield of different maize genotypes

\begin{tabular}{|c|c|c|c|c|c|c|c|c|c|c|c|}
\hline Characters & 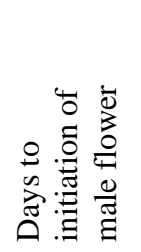 & 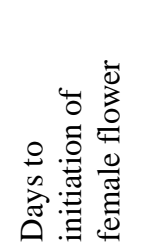 & 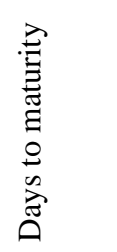 & 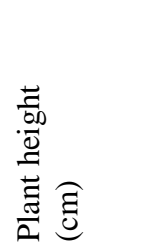 & 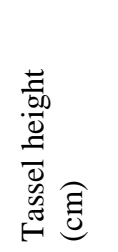 & 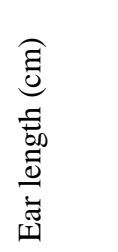 & 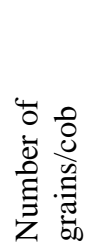 & $\begin{array}{l}\text { हี } \\
\text { ह } \\
\text { 50 } \\
0 \\
0 \\
0 \\
0\end{array}$ & 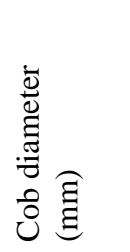 & 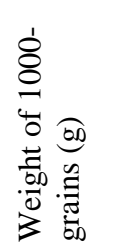 & 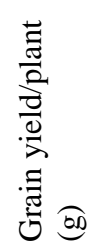 \\
\hline Days to initiation of male flower & $\underline{0.132}$ & -0.109 & 0.168 & -0.098 & 0.230 & 0.079 & -0.158 & -0.207 & -0.133 & -0.059 & -0.155 \\
\hline Days to initiation of female flower & $-\overline{0.167}$ & -0.254 & -0.156 & 0.249 & -0.026 & -0.107 & 0.216 & -0.008 & -0.209 & 0.313 & -0.149 \\
\hline Days to maturity & 0.202 & $\overline{0.055}$ & $\underline{0.178}$ & 0.213 & -0.279 & 0.085 & 0.081 & -0.234 & -0.167 & -0.233 & -0.099 \\
\hline Plant height $(\mathrm{cm})$ & 0.115 & 0.232 & -0.212 & $\underline{0.314}$ & -0.079 & -0.155 & 0.104 & -0.209 & 0.167 & -0.042 & 0.235 \\
\hline Tassel height $(\mathrm{cm})$ & -0.167 & -0.111 & 0.096 & -0.195 & $\underline{0.234}$ & 0.198 & -0.044 & 0.267 & -0.133 & 0.214 & 0.359 \\
\hline Ear length $(\mathrm{cm})$ & -0.109 & 0.071 & -0.215 & 0.067 & $-\overline{0.270}$ & $\underline{0.197}$ & 0.056 & 0.098 & 0.213 & -0.255 & -0.147 \\
\hline Number of grains/cob & 0.178 & -0.143 & 0.222 & -0.047 & 0.294 & 0.194 & $\underline{-0.095}$ & -0.038 & -0.048 & 0.337 & 0.854 \\
\hline Cob length $(\mathrm{cm})$ & 0.139 & 0.212 & -0.155 & 0.234 & -0.118 & 0.167 & $\overline{-0.031}$ & $\underline{0.167}$ & -0.127 & -0.098 & 0.390 \\
\hline Cob diameter $(\mathrm{mm})$ & -0.128 & -0.087 & 0.154 & -0.109 & 0.158 & 0.158 & 0.098 & -0.241 & $\underline{0.168}$ & 0.142 & 0.313 \\
\hline Weight of 1000 -grains (g) & 0.095 & 0.145 & 0.254 & -0.109 & 0.158 & -0.034 & 0.269 & -0.241 & $-\overline{0.065}$ & $\underline{0.217}$ & 0.689 \\
\hline
\end{tabular}

Residual effect $=\mathbf{0 . 2 1 9 8}$ 
It could be concluded from the foregoing discussion that seven trait viz., days to initiation of male flower, days to maturity, plant height $(\mathrm{cm})$, tassel height $(\mathrm{cm})$, ear length $(\mathrm{cm})$, cob length $(\mathrm{cm})$ and cob diameter $(\mathrm{mm})$ had direct and positive effect on grain yield per cob. On the other hand, days to maturity, plant height $(\mathrm{cm})$, tassel height $(\mathrm{cm})$, ear length $(\mathrm{cm})$, cob length $(\mathrm{cm})$ and cob diameter $(\mathrm{mm})$ showed high positive and direct effect on grain yield per cob. There are much scope of improvement of yield if selection pressure is exerted on days to maturity, plant height $(\mathrm{cm})$, tassel height $(\mathrm{cm})$, ear length $(\mathrm{cm})$, cob length $(\mathrm{cm})$ and cob diameter $(\mathrm{mm})$.

\section{REFERENCES}

Abayi, I. K., A. A. Ojo, B. A. Kalu and M. O. Adeyemo. 2000. Genetic variability, heritability and genetic variance in S1 progenies of extra-early and early maize (Zea mays L.) population. J. Sustain. Agric. Environ. 6:179-184.

Ahmed, M., M. A. Mian and M. A. Chowdhury. 2011. Correlation study in maize. J. Agric. Res. 16:399405.

Ahamed, K. U. 2010. Efficacy of indigenous mulches on maize-pulse association. A. Ph.D. Thesis, Department of Crop Botany, Bangladesh Agricultural University, Mymensingh. p.1-202.

Agrawal, K. B. 2002. Characters association and heriatability. Revista Brasileira de Milhoe Sorgo. 1(3): 59-67.

Alvarez, A. and J. M. Lasa. 1994. Collecting and preliminary evaluation of local maize in Northern Spain. Plant Gen. Resource Newsl. 100: 21-23.

BBS. 2014. Annual Agricultural Statistics 2013-14. Bangladesh Bureau of Statistics, Statistic Division, Ministry of Planning, Government people's Republic of Bangladesh, Dhaka, p.37.

Betran, F. J. and A. R. Hallauer. 1996. Characterization of inter-population genetic variability in three hybrid maize populations. J. Heredity. 87: 319-328.

Chowdhury, N. K. and M. A. Islam. (1993). Production and uses Maize (In Bengali). Pub. By on Farm Res. Div. Bangladesh Agril. Inst. Joydebpur, Gazipur. p.1-189.

DAE. 2012. Department of Agriculture Extension. Annual Report for 2011-12. Bangladesh Agricultural University, Mymensingh.

Efferson, K. J. 1982. Comparing farmers and breeders rankings in varietal selection for 1ow-input environments: a case study of rainfed rice in eastern India. Euphytica. 122 (3): 537-550.

Hallauer, A. R. and J. B. Miranda. 1995. Quantitative genetics in maize breeding. ${ }^{\text {edn }}$. Ames: Iowa State and University press, p. 468.

Helm, T.C., A. R. Hallauer and O. S. Smith. 1989. Genetic variability estimate in improved and unimproved Iowa Stiff Stalk Synthetics maize population. Crop Sci. 29:259-962.

Ilarslan, R., Z. Kaya, I. Kandemir and P. K. Bretting. 2002. Genetic variability among Turkish populations, Flint and dent corn (Zea mays spp. Mays) races; morphological and agronomic traits. Euphytica, 128: 173-182.

Jotshi, P. N., B. K. Bhat and M. K. Bhan. 1988. Genetic variability and character association in maize grown in Jammu province. Maize Gen. Coop. Newsl. 62: 105-106.

Kaul, M. L. M. 1985. Genetic divergence analysis in rice. Annals of Biology. 16 (1): 41-44.

Lu, H., Y. L. Zheng, X. Z. Xiong, Li, J. S., Z. Xiong and J. L. Liu. 1994. Allozyme polymorphism within and among local varieties of maize in Southwestern China. Maize Gen. Coop. Newsl. 68: 113115.

Oz, A. 2012. Comparison of hybrid maize obtained from inbred lines that are selected via top-crossing and discriminant analysis. J. Agric. Forest. 36: 659-667.

Prodhan, H. S. and RAI, R. 1997. Genetic variability in popcorn. Indian J. Agric. 41: 287-290.

Rahman, M. M., M. R. Ali, M. K. Islam, M. S. Sultan and B. Mitra. 1995. Correlation and path coefficient studies in maize (Zea mays L.) composites. Bangladesh J. Sci. Indust. Res. 30: 87-92. 
Shahrokhi, P. and Y. P. Khorasani. 2013. Morphological traits variation in maize through different multivariate methods. Intl. J. Agril. Res., 5 (2): 56-63.

Tabanao, D. A. and R. Bernardo. 2005. Genetic variation in maize breeding population with different numbers of parents. Crop Sci. 45: 2301-2306.

Tusuz, M. A. and C. Balabanl. 1997. Heritability of main characters affecting yield of some maize varieties and determination of relationships among these characters. Anadolu. 7(1): 123-134.

Zdunic, Z, A. Mijic, K. Dugalic, D. Simic, J. Brkic and A. Marjanovic-Jeromela. 2008. Genetic Analysis of Grain Yield and Starch Content in Nine Maize Populations. Turkish J. Agric. Forest. 32: 495500.

Zhang, Z. X., Y. L. Zheng, J. S. Li and J. L. Liu. 1995. Allozyme polymorphism and relationships to quantitative traits: diversity of 10 local varieties. Maize Gen. Coop. Newsl. 69: 138-142. 